\title{
ВЛИЯНИЕ СИЛОСА, ЗАГОТОВЛЕННОГО С БИОЛОГИЧЕСКИМИ КОНСЕРВАНТАМИ, НА БИОХИМИЧЕСКИЙ СТАТУС КРОВИ КОРОВ И ИХ ВОСПРОИЗВОДИТЕЛЬНЫЕ ФУНКЦИИ
}

\author{
E.M. Kislyakova, G.A. Khokhryakov, \\ I.M. Manurov, N.M. Togushev
}

\section{THE IMPACT OF SILAGE PREPARED WITH BIOLOGICAL PRESERVATIVES ON BIOCHEMICAL STATUS OF THE COWS' BLOOD AND THEIR REPRODUCTIVE FUNCTIONS}

Кислякова Е.M. - д-р с.-х. наук, профр. кафр. кормления и разведения сельскохозяйственных животных Ижевской государственной сельскохозяйственной академии, г. Ижевск.

E-mail: mullan@inbox.ru

Хохряков Г.А. - асп. каф. кормления и разведения сельскохозяйственных животных Ижевской государственной сельскохозяйственной академии, г. Ижевск.

E-mail: hogriant@gmail.com

Мануров И.М. - канд. С.-х. наук, доц. каф. физической культуры Ижевской государственной сельскохозяйственной академии, г. Ижевск

E-mail: mullan@inbox.ru

Тогушев Н.M. - канд. с.-х. наук, доц. каф. кормления и разведения сельскохозяйственных животных Ижевской государственной сельскохозяйственной академии, г. Ижевск.

E-mail: mullan@inbox.ru

Цель исследования - сравнительное изучение эфроективности консервантов «Лаксил» и «Биоамид-З» при силосовании профилирующей кормовой культуры. Задачи исследования: изучить биохимический статус крови коров на фоне рационов кормления, в состав которых входил силос, заготовленный с различными биологическими консервантами; установить влияние изучаемого силоса на основные показатели воспроизводительных функций коров. Исследования проведены в АО «Восход» Шарканского района Удмуртской Республики. Было проведено силосование люцерны с внесением биологических консервантов «Лаксил» и «Биоамид-3», один вариант закладывался без консервантов. Продуктивное действие изучалось на mрех группах коров, отобранных методом
Kislyakova E.M. - Dr. Agr. Sci., Prof., Chair of Farm Animals Feeding and Breeding, Izhevsk State Agricultural Academy, Izhevsk.

E-mail: mullan@inbox.ru

Khokhryakov G.A. - Post-Graduate Student, Chair of Farm Animals Feeding and Breeding, Izhevsk State Agricultural Academy, Izhevsk.

E-mail: hogriant@gmail.com

Manurov I.M. - Cand. Agr. Sci., Assoc. Prof., Chair of Physical Culture, Izhevsk State Agricultural Academy, Izhevsk

E-mail: mullan@inbox.ru

Togushev N.M. - Cand. Agr. Sci., Assoc. Prof., Chair of Farm Animals Feeding and Breeding, Izhevsk State Agricultural Academy, Izhevsk.

E-mail: mullan@inbox.ru

пар-аналогов. Биохимический статус определяли взятием крови через 30 и 60 дней от начала скармливания изучаемых рационов. Содержание белка в сыворотке крови при первом анализе находилось в пределах рефрерентных значений, но ближе к нижней границе. В крови коров всех групп была выявлена гипогликемия. На фоне силоса с «Биоамид-3» уровень глюкозы был достоверно выше аналогов контрольной группы на 16,13 мг\%. В динамике увеличивается содержание белка в сыворотке крови всех животных, на фоне силоса с «Биоамидом-З» преимущество существенное. Установлено улучшение энергетического обмена, так как содержание глюкозы было больше на 13,46 мг\%, или на 33,3 \%, по отношению к контролю, наблюдалось увеличение концентрации кароти- 
на в крови на 0,21 мг\%. Внесение в силосуемое сырье (люцерну) консерванта «Биоамид-3» позволяет снизить кратность осеменения на 1,2 и улучшает коэфрфициент воспроизводительной способности на 0,03.

Ключевые слова: биологические консерванты, «Лаксил», «Биоамид-З», кормовые культуры, качество корма, коровы, биохимический анализ крови.

The research was aimed at comparative study of the effectiveness of Laxil and Bioamid-3 preservatives in ensilaging of specific forage crop. The research problems were to study biochemical status of cows' blood against the background of feeding diets, which included silage harvested with various biological preservatives; to establish the impact of studied silage on the main indicators of reproductive functions of cows. The research was carried out in JSC"Voskhod", Sharkansk district of the Udmurt Republic. Alfalfa was ensilaged with application of biological preservatives Laxil and Bioamide-3, one option was taken without preservatives. Productive effect was studied on three groups of cows selected by couples' analogue method. Biochemical status was determined by taking blood after 30 and 60 days from the beginning of feeding the studied diets. The protein content in blood serum at the first analysis was within the reference values, but closer to the lower limit. Hypoglycemia was detected in the blood of cows of all groups. Silage with Bioamid-3 resulted in the glucose level significantly higher than the control group analogues by $16.13 \mathrm{mg} \%$. In dynamics the protein content in blood serum of all the animals' silage with Bioamid-3 resulted in significant increase. The improvement in energy metabolism was found, since the glucose content was greater by $13.46 \mathrm{mg} \%$ or $33.3 \%$ versus the control group, the concentration of carotene in the blood increased by $0.21 \mathrm{mg} \%$. Application of Bioamid-3 preservative to ensilaged raw material (alfalfa) makes it possible to reduce the number of inseminations by 1.2 and improves the coefficient of reproductive capacity by 0.03 .

Keywords: biological preservatives, "Laxil", "Bioamid-3", forage crops, forage quality, biochemical blood test.
Введение. Основной задачей кормопроизводства является заготовка качественных объемистых кормов с концентрацией обменной энергии не менее 10 МДж в сухом веществе [8, 11]. В условиях Западного Предуралья, а в частности Удмуртской Республики, с непостоянством климатических условий это проблематично [5]. Основу кормопроизводства в нашем регионе составляют многолетние бобовые травы, в частности люцерна и клевер, при силосовании которых использование консервантов является обоснованным [2].

На сегодняшний день в практике кормозаготовки используют десятки различных консервантов, хотя механизм их действия недостаточно изучен [3]. Огромный ассортимент консервантов обуславливает необходимость разумного их выбора для силосования, что является важным моментом в кормопроизводстве $[1,10]$. Особую актуальность этот вопрос приобретает при дождливой погоде. Сравнительный анализ эфффективности применения биологических консервантов при закладке силоса из профилирующих кормовых культур в условиях Удмуртской Республики ранее не проводился.

Цель исследования: сравнительное изучение эфффективности консервантов «Лаксил» и «Биоамид-3» при силосовании профрилирующих кормовых культур.

\section{Задачи исследования:}

- изучить биохимический статус крови коров на фроне рационов кормления, в состав которых входил силос, заготовленный с различными биологическими консервантами;

- установить влияние изучаемого силоса на основные показатели воспроизводительных функций коров.

Материал и методы исследования. Производственные испытания и научно-хозяйственные исследования были проведены на базе $\mathrm{AO}$ «Восход» Шарканского района Удмуртской Республики, которое является племенным репродуктором по разведению холмогорской породы крупного рогатого скота.

Согласно схеме исследования, при силосовании в качестве сырья использовали профилирующую для нашей зоны культуру, в частности люцерну [7]. Нами были заложены производственные исследования - заготовка силоса в траншеях. В производственных опытах были 
задействованы три бетонированные траншеи объемом 1000 т. Силосование проводилось одновременно. В сырье вносились консерванты «Лаксил» и «Биоамид-З», один вариант служил контролем и закладывался без консервантов. Изучалось продуктивное действие заготовленного силоса. С этой целью было сфрормировано три группы коров в первый месяц лактации методом пар-аналогов по 12 голов в каждой [4]. В состав рациона вводили силос, заготовленный с использованием изучаемых консервантов [9]. В течение опыта все животные содержались в аналогичных условиях и получали одинаковый рацион, различие было в использовании силоса. Животным первой группы в состав рациона вводили силос, приготовленный с «Лаксилом», второй опытной группе - силос, заготовленный с использованием консерванта «Биоамид-3». Одна группа являлась контролем.

Биохимический статус определяли взятием крови на фоне изучаемых рационов кормления от пяти коров. Кровь отбиралась через 30 дней от начала скармливания изучаемых рационов и в динамике через 60 дней [6]. Анализ проводился в Удмуртском ветеринарно-диагностическом центре по общепринятым методикам. В крови изучали содержание общего уровня белка для характеристики белкового обмена, изучали содержание общего уровня глюкозы для определения энергетического уровня питания. Каротин является провитамином витамина А. Десицит витамина А нарушает энергетический обмен. В связи с этим определялось содержание каротина в сыворотке крови. Устанавливалась также резервная щелочность в исследуемых образцах. Полученный материал обработан методом вариационной статистики.

Результаты исследования. Полноценное кормление, правильное содержание и наследственные свойства являются основными факторами, способствующими повышению молочной продуктивности крупного рогатого скота, и являются главными условиями улучшения эффективности отрасли животноводства.

Контроль за состоянием обмена веществ животных в хозяйстве осуществляется на основании биохимических исследований крови.

Изучение крови, как одной из разновидностей тканей внутренней среды, имеет важнейшее диагностическое значение. Контроль кормления в зоотехнии осуществляется по показателям крови, которые в комплексе с другими позволяют выявить скрытые, не проявляющиеся клинические изменения в органах и тканях, а также судить о функциональном состоянии как отдельных органов, так и всего организма.

Биохимические исследования крови были проведены через месяц после начала скармливания изучаемых рационов (табл. 1) и в динамике через 60 дней использования.

Таблица 1

\section{Основные биохимические показатели крови коров через 30 дней кормления}

\begin{tabular}{|l|c|c|c|}
\hline \multicolumn{1}{|c|}{ Показатель, мг\% } & \multicolumn{3}{|c|}{ Группа } \\
\cline { 2 - 4 } & Контрольная & Первая опытная & Вторая опытная \\
\hline Содержание белка & $7,51 \pm 0,16$ & $7,88 \pm 0,20$ & $7,88 \pm 0,17$ \\
\hline Содержание сахара & $13,63 \pm 0,98$ & $16,96 \pm 1,67$ & $29,76 \pm 1,51^{\star \star \star ~}$ \\
\hline Содержания кальция & $11,79 \pm 0,22$ & $11,70 \pm 0,16$ & $11,42 \pm 0,14$ \\
\hline Содержания фосфрора & $6,44 \pm 0,40$ & $6,61 \pm 0,40$ & $5,89 \pm 0,15$ \\
\hline Содержание каротина & $0,24 \pm 0,02$ & $0,31 \pm 0,02^{\star}$ & $0,35 \pm 0,03^{\star \star}$ \\
\hline Щелочной резерв & $47,17 \pm 2,13$ & $50,50 \pm 2,55$ & $51,22 \pm 0,78$ \\
\hline
\end{tabular}

* $P \geq 0,950$; ** $P \geq 0,990$; *** $P \geq 0,999$.

Первый период приходился на раздой коров и характеризовался высокой интенсивностью обменных процессов, что сказалось на результатах анализа. Содержание белка в сыворотке крови характеризует белковый обмен. Результаты первого анализа свидетельствовали, что этот показатель находился в пределах референтных значений, но ближе к нижней границе. Содержание общего уровня глюкозы определяли для характеристики энергетического уровня питания. В крови коров всех групп была выявлена гипогликемия. Самые низкие значения ус- 
тановлены в образцах крови коров контрольной группы. Для периода начала лактации пониженный уровень сахара в крови свидетельствует об отрицательном энергетическом балансе. Можно отметить, что в образцах крови второй опытной группы уровень этого показателя был достоверно выше аналогов контрольной группы на 16,13 мг\%.

Содержание каротина при первом анализе также было ниже физиологической нормы во всех группах. Наименьший уровень наблюдался у коров контрольной группы, получавших в рационе силос без консерванта. В свою очередь, скармливание силоса, заготовленного с биологическими консервантами, способствует увеличению этого показателя в крови животных опытных групп на 0,07-0,11 мг\%, или на 29,0-45,8 \% $(P \geq 0,990)$.

Повторный анализ биохимических показателей крови, представленный в таблице 2, выявил, что в динамике увеличивается содержание белка в сыворотке крови всех животных, при этом при скармливании силоса с «Биоамид-З» наблюдалось достоверное превышение показателя над аналогами из контрольной группы (P $\geq 0,95)$.

Таблица 2

\section{Основные биохимические показатели крови коров через 60 дней кормления}

\begin{tabular}{|l|c|c|c|}
\hline \multicolumn{1}{|c|}{ Показатель, мг\% } & \multicolumn{3}{|c|}{ Группа } \\
\cline { 2 - 4 } & Контрольная & Первая опытная & Вторая опытная \\
\hline Содержание белка & $7,71 \pm 0,15$ & $7,95 \pm 0,18$ & $8,17 \pm 0,09^{*}$ \\
\hline Содержание сахара & $40,44 \pm 2,97$ & $48,80 \pm 4,65$ & $53,90 \pm 3,32^{\star *}$ \\
\hline Содержания кальция & $11,58 \pm 0,23$ & $11,44 \pm 0,35$ & $11,27 \pm 0,29$ \\
\hline Содержания фросфора & $5,08 \pm 0,43$ & $6,30 \pm 0,49$ & $5,17 \pm 0,46$ \\
\hline Содержание каротина & $0,24 \pm 0,03$ & $0,35 \pm 0,05$ & $0,45 \pm 0,05^{\star}$ \\
\hline Щелочной резерв & $51,20 \pm 1,23$ & $58,68 \pm 3,82$ & $56,24 \pm 1,61$ \\
\hline
\end{tabular}

* $P \geq 0,950 ;{ }^{* \star} P \geq 0,990$.

С течением лактации улучшился энергетический обмен, о чем свидетельствует нормализация уровня сахара в крови, при этом лучшие характеристики получены у животных второй опытной группы. Содержание сахара у них было больше на 13,46 мг\%, или на $33,3 \%$, по отношению к контролю (P $\geq 0,990)$. На фоне силоса c «Лаксилом» также наблюдалось повышение уровня сахара на 8,36 мг\%, но разница не имела статистической значимости.

Наблюдалось увеличение концентрации каротина в крови животных опытных групп, при этом на фоне скармливания силоса с «Биоамид-3» этот показатель находился в пределах референтных значений. При сравнении результатов между группами следует отметить существенное преимущество второй опытной группы над аналогами из контрольной (P $\geq 0,990)$. Разница составила 0,21 мг\%. По остальным показателям существенных различий не обнаружено, и они находились в пределах физиологических норм.

Устанавливалась также резервная щелочность в исследуемых образцах, так как снижение ее уровня свидетельствует об ацидозах (недостаток щелочного эквивалента). Это может наблюдаться на фоне избыточного потреблении легкоферментируемых углеводов при использовании повышенных норм концентратов, а также когда в рационах преобладают кислые корма, содержащие в большом количестве уксусную и масляную кислоты. В наших исследованиях щелочной резерв крови находился в пределах физиологических норм.

Считаем, что нормализация биохимического статуса крови является следствием скармливания качественного корма, заготовленного с применением биологических консервантов. Лучшим влиянием на физиологическое состояние обладал силос, заготовленный с «Биоамид-3».

Для успешной интенсификации молочного скотоводства необходимо создавать не только высокопродуктивные стада, но и улучшать их воспроизводительные качества. Полноценное кормление является основой поддержания репродуктивных фуункций коров. Нами изучены показатели воспроизводства подопытных животных на фроне скармливания силоса, заготовленного с различными консервантами (табл. 3). 
Показатели воспроизводительных функций подопытных коров

\begin{tabular}{|l|c|c|c|}
\hline \multirow{2}{*}{ Показатель } & \multicolumn{3}{|c|}{ Группа } \\
\cline { 2 - 4 } & Контрольная & Первая опытная & $\begin{array}{c}\text { Вторая опыт- } \\
\text { ная }\end{array}$ \\
\hline $\mathrm{n}$ & 12 & 12 & 12 \\
\hline Продолжительность сервис-периода, дн. & $130,83 \pm 20,53$ & $130,42 \pm 15,82$ & $119,25 \pm 16,44$ \\
\hline Кратность осеменения & $2,95 \pm 0,22$ & $2,83 \pm 0,42$ & $1,75 \pm 0,33^{\star \star}$ \\
\hline Межотельный период, дн. & $415,70 \pm 29,99$ & $417,10 \pm 25,76$ & $402,60 \pm 28,66$ \\
\hline КВС & 0,88 & 0,88 & 0,91 \\
\hline
\end{tabular}

${ }^{*} P>0,95,{ }^{* *} P>0,99$.

Отмечено улучшение показателей воспроизводства у коров второй опытной группы. Так, продолжительность сервис-периода у них была меньше на 11,6 дня. Кратность осеменения снизилась на 1,2 при достоверной разнице (P $\geq 0,990)$. Улучшение результативности осеменения позволяет сократить продолжительность межотельного периода на 13 дней и улучшить коэффициент воспроизводительной способности.

Выводы. Использование биологических консервантов при силосовании является эфрфективным приемом в интенсификации отрасли молочного скотоводства. Лучшим физиологическим эфффектом обладал биологический консервант «Биоамид-3». На фоне введения в рацион силоса с «Биоамидом-З» в крови увеличивается концентрация глюкозы (сахара) и каротина.

Наши исследования проиллюстрировали зависимость показателей воспроизводства от полноценности кормления и качества кормов. Внесение в силосуемое сырье (люцерну) консерванта «Биоамид-3» позволяет снизить кратность осеменения на 1,2 и улучшает коэффицциент воспроизводительной способности на 0,03.

\section{Литература}

1. Аветисян А.А., Колесников В.А., Аветисян А.T. Питательность и продуктивность перспективных видов кормовых культур в лесостепи Восточной Сибири // Вестн. КрасГАУ. 2017. - № 10 (133). - С. 22-32.

2. Биологические препараты в консервировании зеленой массы люцерны / Ф.Р. Вафрин [и др.] // Вестн. технолог. ун-та. - 2017. № 8. - C. 131-133.
3. Валиуллина Р.Д., Коконов С.И. Кормовые ресурсы - основа стабильного кормопроизводства Удмуртской Республики // Современному АПК - эффрективные технологии: мат-лы междунар. науч.-практ. конф. Ижевск, 2019. - Т. 1. - С. 78-82.

4. Зайцева О.В., Лефлер Т.Ф., Курзюкова Т.А. Эффрективность производства молока при разных способах содержания коров // Вестн. КрасГАУ. - 2019. - № 4 (145). C. 67-74.

5. Коконов С.И., Кислякова Е.М. Перспективные направления кормопроизводства Удмуртской Республики // Актуальные вопросы растениеводства и кормопроизводства в XXI веке: мат-лы междунар. науч.-практ. конфр. - Кинель, 2017. - С. 21-24.

6. Кузнецов С.Г., Кузнецова Т.С., Кузнещов А.С. Биохимические критерии полноценности кормления животных // Ветеринария. 2008. - № 4. - С. 3-9.

7. Молочная продуктивность коров при использовании в рационе силоса, заготовленного с новым консервантом-обогатителем / И.Ф. Горлов [и др.] // Вестн. Алтайского гос. аграр. ун-та. - 2015. № 11 (133). - С. 91-96.

8. Пути интенсификации кормопроизводства в Красноярском крае / Л.П. Байкалова [и др.] // Вестн. КрасГАУ. - 2018. - № 5 (140). - C. 102-108.

9. Продуктивность и питательная ценность кормовых культур в условиях Сибири / В.К. Ивченко [и др.] // Вестн. КрасГАУ. 2016. - № 11. - C. 9-15. 
10. MacLeod G.K. Feeding affects milk test // Can. Ayrshiere Review. - 2016. - V. 48, № 8. P. 16-17.

11. Shaver R.D., Howard W.T. Feeding Dairy Cows For Efficient Reproductive Performance // Agriculture Publications. - 2010-2011. - URL: http://learningstore.uwex.edu/pdf/ncr366.pdf.

\section{Literatura}

1. Avetisyan A.A., Kolesnikov V.A., Avetisyan A.T. Pitatel'nost' i produktivnost' perspektivnyh vidov kormovyh kul'tur v lesostepi Vostochnoj Sibiri // Vestn. KrasGAU. - 2017. - № 10 (133). - S. 22-32.

2. Biologicheskie preparaty $\mathrm{v}$ konservirovanii zelenoj massy lyucerny / F.R. Vafin [i dr.] // Vestn. tekhnolog. un-ta. - 2017. - № 8. S. 131-133.

3. Valiullina R.D., Kokonov S.I. Kormovye resursy - osnova stabil'nogo kormoproizvodstva Udmurtskoj Respubliki // Sovremennomu APK - effektivnye tekhnologii: mat-ly mezhdunar. nauch.-prakt. konf. - Izhevsk, 2019. - T. 1. - S. 78-82.

4. Zajceva O.V., Lefler T.F., Kurzyukova T.A. Effektivnost' proizvod-stva moloka pri raznyh sposobah soderzhaniya korov // Vestn. KrasGAU. - 2019. - № 4 (145). - S. 67-74.
5. Kokonov S.I., Kislyakova E.M. Perspektivnye napravleniya kormopro-izvodstva Udmurtskoj Respubliki // Aktual'nye voprosy rastenievodstva i kormoproizvodstva $\mathrm{v}$ XXI veke: mat-ly mezhdunar. nauch.-prakt. konf. Kinel', 2017. - S. 21-24.

6. Kuznecov S.G., Kuznecova T.S., Kuznecov A.S. Biohimicheskie kriterii polnocennosti kormleniya zhivotnyh // Veterinariya. - 2008. № 4. - S. 3-9.

7. Molochnaya produktivnost' korov pri ispol'zovanii v racione silosa, zagotovlennogo s novym konservantom-obogatitelem / I.F. Gorlov [i dr.] // Vestn. Altajskogo gos. agrar. un-ta. - 2015. - № 11 (133). - S. 91-96.

8. Puti intensifikacii kormoproizvodstva $\mathrm{V}$ Krasnoyarskom krae / L.P. Bajkalova [i dr.] // Vestn. KrasGAU. - 2018. - № 5 (140). S. 102-108.

9. Produktivnost' i pitatel'naya cennost' kormovyh kul'tur v usloviyah Sibiri / V.K. Ivchenko [i dr.] /I Vestn. KrasGAU. - 2016. - № 11. - S. 9-15.

10. MacLeod G.K. Feeding affects milk test // Can. Ayrshiere Review. - 2016. - V. 48, № 8. P. 16-17.

11. Shaver R.D., Howard W.T. Feeding Dairy Cows For Efficient Reproductive Performance // Agriculture Publications. - 2010-2011. - URL: http://learningstore.uwex.edu/pdf/ncr366.pdf. 